river, or east and west. On the northern side of this cutting, nearest the river, the bed is several feet in thickness; but on the other side it thins out, and finally disappears as we recede from the shore. In the other direction, from east to west, it is seen to abut suddenly against the Boulder-clay, and thus occupies a hollow of no great extent, in which, however, an immense number and variety of marine organisms are crowded together, forming one of the richest beds of such clay yet discovered on our western coast. At the same time, there was reason to doubt whether the deposit is now found in its natural position, or has not been dug out from some neighbouring part of the shore, and laid down to improve and level the ground, many years ago, in forming the policies where the excavation is being made. On this point, however, he would not express a decided opinion, and other members who had visited the spot were not unanimous regarding it.

Mr. Young said the section of Boulder-clay and the shell-bed referred to were of great interest, and he hoped would receive a careful examination from the members of the Society. He alluded to the number of large boulders, found principally in the upper portion of the deposit, the majority being sandstone of local origin, and the remainder granite, trap, and schist, from more distant localities. Many of these boulders were beautifully smoothed and striated by the action of ice. With regard to the puzzling features presented by the shell-clay--the way in which the shells are huddled together, the absence of any distinct stratification in it, and the manner in which it abuts suddenly against the Boulder-clay on either hand-these circumstances, together with its being of a looser texture, or less firmly compacted than most of the Arctic shell-beds found on our coast, undoubtedly suggest that it has been disturbed and removed. On the other hand, he read a note from Mr. Darid Robertson, whose opinion in such matters was entitled to very great weight, pointing out that a thin bed of fine clay, in which marine organisms occur, extends continuously between the shell-bed and the anderlying Boulder-clay - which seems opposed to the supposition of the shell-clay having been laid down on an old land surface. Apart from this point (Mr. Young added), the deposit is worthy of attention as being exceedingly rich in organic remains, about 140 species having been already obtained from it, including some rare and many well-known Arctic forms.

An arranged series of these shells, polyzoa, etc., was exhibited by Mr. Young and Mr. Glen. Several other members also remarked on the deposit, and arrangements were made to revisit the locality at an early date.

\title{
COREFSPOINDEINOF.
}

On Supposwd Pholas-burrows in Mulerg Dale, near Buxton, DrerbYshrRe.

Sir,-From a letter in the Geologicar, Magazine (Vol. VII., p. 586), I perceive that Mr. Edwin Brown, F.G.S., was unable to find 
the burrowings in Limestone which $I$ described as occurring in Millers Dale. Perhaps he may have overlooked them, or possibly, as they were not numerous, some other person may have broken them away. I was reluctantly obliged to detach a specimen myself (which I send herewith) for the confutation of the incredulous. To insinuate that I do not know 'Toadstone' from 'Limestone,' or should write in a scientific periodical after an examination called 'careful' by myself, but in reality so hurried as to mistake the one for the other, or indeed the "vesicular cavities" of toadstone for "the borings of animals," attributes to me ignorance so gross, or carelessness so reprehensible, that Mr. Brown might as well have said that he considered me unworthy to write F.G.S after my name.

ST. John's Collegr,

Cambridar, Dec. 5.

T. G. Bonney.

P.S.-With regard to the principal subject of Mr. Brown's communication, I may remark that the following instances confirm, if it be needed, the idea of some, at least, of the Toadstones not being intrusive. (1). In a small cliff close by Litton Mills, at the opening of Cressbrook Dale (left bank), we have the following section :(A) High talus overgrown with bushes, showing projecting ledges of limestone: (B) Cliff of Toadstone, upper part sandy and decomposing, lower part more solid and amygdaloidal : (c) well marked bed of very compact Toadstone : (D) sandy and shaly band, volcanic ashes: (I) ashy bed, nodular and concretionary in places, with fossils, Spirifera Productus, etc. : (F) Limestone, very compact, perhaps somewhat altered. (2). In descending by the road that leads over the flanks of the Heights of Abraham from Matlock Bath to Bonsall, after quitting the sheet of Toadstone that caps the hill, I observed many blocks in the wall containing volcanic ash. One variety is a purple rock of clayey fracture, containing angular or subangular fragments of limestone, and yellowish brown or greenish bits and specks, which $I$ believe to be decomposing volcanic ash; the other a calcareous rock (? brecciated in places) with many specks of greenish grey and brown colour, also decomposing ashes. This bed contains fragments of small crinoids. If I mistake not, both these beds are exposed in situ by the road-side a short distance apart, and about fifty yards from the first cottage in Bonsall village.-T.G.B.

In the Geologiond Magazine for June last (Vol. VII.,p. 267) we published an article on supposed Pholas-burrows in Millers Dale, by the Rev. T. G. Bonney, M.A., F.G.S.

Another article " on the supposed oocurrence of Pholas-burrows in the upper parts of the Great and Little Ormesheads," by the same author (accompanied by a Plate), appeared in Vol. VI., 1869, p. 483.

Mr. Bonney's observations tend to disprove their Pholas-origin, and to support the conclusions of M. Bouchard-Chantereaux, Miss Hodgson, and others, that they are the work of Helices.

In a letter published in the December number of this Magazine 
(p. 586, Vol. VII.), Mr. Edwin Brown calls in question the fact of perforated Limestone occurring in Millers Dale, and supposes that Mr. Bonney may have mistaken vesicular cavities in Toadstone for the borings of animals in Limestone.

Mr. Bonney very justly complains of the unfairness of Mr. Brown's insinuation, which, we regret to say, did not strike us in reading Mr. Brown's letter before publication. We have received from Mr. Bonney a specimen of the perforated Limestone from Millers Dale, referred to in his article, and it is, as our readers would expect, a true Limestone, the perforations of which agree exactly with those from Ulverston, in Lancashire, originally described by Miss Hodgson (see the "Geologist," Vol. vii., 1864, p. 42), and subsequently by Mr. J. Rofe, F.G.S. (See GroL. MAG., Vol. VII., 1870, p. 4, Pl. I.)

The estimate our readers and other scientific men have formed of Mr. Bonney's contributions to science, would prevent any one accepting the suggestion in Mr. Brown's letter. We are sorry this paragraph formed a portion of an otherwise valuable communication; and we do not doubt that Mr. Brown will be as ready as we are to regret what he must now see was an unjust criticism on the observations of a brother F.G.S. Edit. Geol. Mag.

\section{THE BLUE CLAY OF THE WEST OF ENGLAND.}

SrR,-Miss Eyton states (Grox. MAG., p. 545) that the shellbearing gravels often rest "upon a bed of blue or grey clay . . . desoribed . . . in Lancashire and Cheshire, by Mr. Binney ; and more recently by Prof. Hull," and mentions that Mr. Hull gives its thickness at Llandudno at 150 feet. To Prof. Hull's name she gives a reference to a paper on the "Glacial Phenomena of Lancashire and Cheshire." I wish to state (1), that I am the writer of a paper with that title, read before the Geological Society, on June 22nd. (2), That Prof. Hull has not, I believe, written a paper with that title. (3), That the Lower Till he has always described as precisely resembling the Upper Till, being of the same red colour, general character, and including the same erratic boulders. (4), That this is so much the case, that Mr. Binney considers (in all his papers) the two clays to be one, with an intercalated Middle Sand. (5), That in my paper, above referred to, I describe a Lower Till, of the nature mentioned by Miss Eyton, as occurring in Lancashire, at levels above 300 feet, formed by an ice-sheet, and mention that in North Wales a similar clay is eroded, and overlaid by the ordinary Lower Boulder-clay of marine origin. (6), That I consider that at Llandudno it never reaches a greater thickness than 20 feet. (7), That I cannot admit, with Mr. S. V. Wood, that the Upper Till of Lancashire is the representative of the Hessle clay, or any other recent bed.

H. M. Geologicat Surtey, Morecambe. C. E. De Ranom, F.G.S. 